\title{
Treatment of slaughterhouse wastewater in a UASB reactor and an anaerobic filter.
}

1. Ruiz, M. C. Veiga, P. de Santiago \& R. Blázquez

Bioresource Technology, Volume 60, Issue 3, June 1997, Pages 251-258

DOI: 10.1016/S0960-8524(97)00020-5

\begin{abstract}
A study was performed to assess the feasibility of anaerobic treatment of slaughterhouse wastewaters in a UASB (Upflow Anaerobic Sludge Blanket) reactor and in an AF (Anaerobic Filler). Among the different streams generated, the slaughter line showed the highest organic content with an average COD of $8000 \mathrm{mg} / 1$, of which $70 \%$ was proteins. The suspended solids content represented between 15 and $30 \%$ of the COD. Both reactors hada working volume of 21 . They were operated at $37^{\prime} \mathrm{C}$. The UASB reactor was run at OLR (Organic Loading Rates) of $1-6.5 \mathrm{~kg} \mathrm{COD} / \mathrm{m}^{3}$ day. The COD removal was $90 \%$ for OLR up to $5 \mathrm{~kg}$ $\mathrm{COD} / \mathrm{m}^{3} /$ day and $60 \%$ for an $\mathrm{OLR}^{\prime}$ of $6.5 \mathrm{~kg} \mathrm{COD} / \mathrm{m}^{3}$ day. For similar organic loading rates, the AF showed lower, removal efficiencies and lower percentages of methanization. At higher OLR sludge, flotation occur- red and consequently the active biomass was washed out from the filler. The results indicated that anaerobic treatment systems are applicable to slaughterhouse wastewaters and that the UASB reactor shows a better performance, giving higher COD removal efficiencies than the AF. (C) 1997 Elsevier Science Ltd.
\end{abstract}

Keywords: Anaerobic filter, slaughterhouse waste-water, UASB, ammonium, proteins.

$\begin{array}{ll}\text { NOMENCLATURE } \\ \mathrm{f} & \text { feed } \\ \mathrm{e} & \text { effluent } \\ \mathrm{g} & \text { gas } \\ \mathrm{s} & \text { soluble } \\ \text { in } & \text { insoluble }\end{array}$




\section{INTRODUCTION}

Slaughterhouse wastewaters are considered by the different European legislations as 'very contaminating' (Tritt \& Schuchardt, 1992) due to their composition, characterized mainly by a complex mixture of fats, proteins and fibers. The organic matter concentration is medium to high and the residues are partially solubilized, leading to a highly contaminating effect in riverbeds or sewer systems if the wastewater is not previously treated.

In Galicia, a region of Northern Spain, there are more than 80 working slaughterhouses, producing more than $800,000 \mathrm{~m}^{3}$ wastewater per year. Flow rates and composition of the effluents vary significantly from one installation to another, with COD concentrations ranging from 1500 to 16,000 mg/1 and TSS concentrations ranging from 300 to $11,000 \mathrm{mg} / 1$ (Ruiz et al., 1993).

Physical-chemical methods and aerobic processes have been used for the treatment of this type of wastewater (Sáez \& y Martínez, 1987; Couillard et al., 1989; Gariépy et al., 1989; Tritt \& Schuchardt, 1992). Anaerobic processes have been proposed as a good alternative for the treatment of wastewaters with high or medium organic loads (Hickey et al., 1992). They are suitable for the treatment of effluents from agroindustries. The advantages of anaerobic processes are biogas production, low generation of sludge, no aeration costs and elimination of pathogens (Mateu et al., 1992).

There are several studies showing the viability of the anaerobic process for the treatment of slaughter- house wastewaters (Sayed et al., 1984; Sayed et al.,1987; Sayed et al., 1988a; Sayed \& de Zeeuw, 1988b; Peláez et al., 1989; Marchaim et al., 1991; Ruiz, 1992). However, it has not been used extensively on a large scale.

The present work deals with the characterization of the different wastewater ftows from a slaughter- house and the evaluation of the performance of two continuous reactors, an AF and an UASB reactor, for treating slaughterhouse wastewater which had not had previous removal of the blood and so was of high protein content.

\section{METHODS}

The experiments were carried out using an Upflow Anaerobic Sludge Blanket reactor (UASB) and an anaerobic filter (AF) packed with corrugated PVC Raschig rings as support material. Both reactors were placed in a thermostatic chamber and were run at a constant temperature of $37^{\circ} \mathrm{C}$. The sketch of the experimental set-up is the same for both reactors, except for the support material, which was used only in the AF (Fig. 1). Both reactors were $54 \mathrm{~cm}$ high, with an internal diameter of $8 \mathrm{~cm}$, giving a working volume of $2 \mathrm{l}$. The feed and recirculation flow rates were controlled by intermittent pumping at regular intervals. The wastewater used as feed was maintained in a refrigerator at $4^{\circ} \mathrm{C}$. It had been previously filtered to eliminate suspended solids greater than $1 \mathrm{~mm}$ diameter. lt was maintained in a feed reservoir with a mixer to ensure homogeneity.

The reactors were inoculated with a flocculent sludge originating from a pilotscale contact anaerobicreactor treating wastewaters from a seafood-processing factory (Veiga et al., 1994). The UASB reactor was inoculated with 21 sludge. Yolatite suspended solids (VSS) content of the sludge was $16 \mathrm{~g} / 1$ and its maximum methanogenic activity was $0.53 \mathrm{~g} \mathrm{COD}_{\mathrm{CH} 4} / \mathrm{g}$ VSS/day. The AF was inoculated with 1.81 sludge with a VSS concentration of $27.7 \mathrm{~g} / 1$ and a maximum methanogenic activity of0.64 $\mathrm{g} \mathrm{COD}_{\mathrm{CH} 4} / \mathrm{g}$ VSS/day.

The influent and effluent flow rates, and the biogas production were monitored daily. 
The following reactor parameters were checked regularly: temperature, $\mathrm{pH}$ and redox potential. Total and soluble COD (for the soluble COD, a sample was filtered with a glass microfiber filter $0.45 \mathrm{~J} . \mathrm{m}$ pore size), alkalinity, volatile fatty acids/total alkalinity (VFN TA), proteins, ammonium, phosphates, VSS and total suspended solids (TSS) were measured in the influent and effluent, and the biogas composition was determined.

$\mathrm{pH}$, redox potential and ammonium concentration were determined using ionselective electrodes. COD, TSS, VSS and phosphate determinations were carried out as proposed by Standard Methods (APHA-AWWA-WPCF, 1992). The protein content was measured by the method of Lowry (Lowry et al.,

1951). Alkalinity and VFA/TA ratio were measured by sample titration with sulphuric acid, and the biogas composition with an Orsat apparatus.

The batch biodegradability of the wastewater which was used for feeding the reactors was deter- mined using the methodology described by Soto et al. (1993).

The methanogenic activities were determined in batch assays (Soto et al., 1993), using a VFA mixture (acetic acid, $2.0 \mathrm{~g} / \mathrm{l}$; propionic acid, $0.5 \mathrm{~g} / \mathrm{l}$ and n-butiric acid $0.5 \mathrm{~g} / \mathrm{l}$ as substrate. VFA were analyzed on a Hewlett-Packard model 5890A gas chromatograph equipped with a flame ionization detector. The capillary column (nukol phase, 30m length and $0.25 \mathrm{~mm}$ internal diameter) was operated between 120 and $170^{\circ} \mathrm{C}$ with a rise of $20^{\circ} \mathrm{C}$ per min, with a nitrogen carrier flow rate of $2 \mathrm{ml} / \mathrm{min}$, and injector and detector temperatures of 270 and $250^{\circ} \mathrm{C}$, respectively.

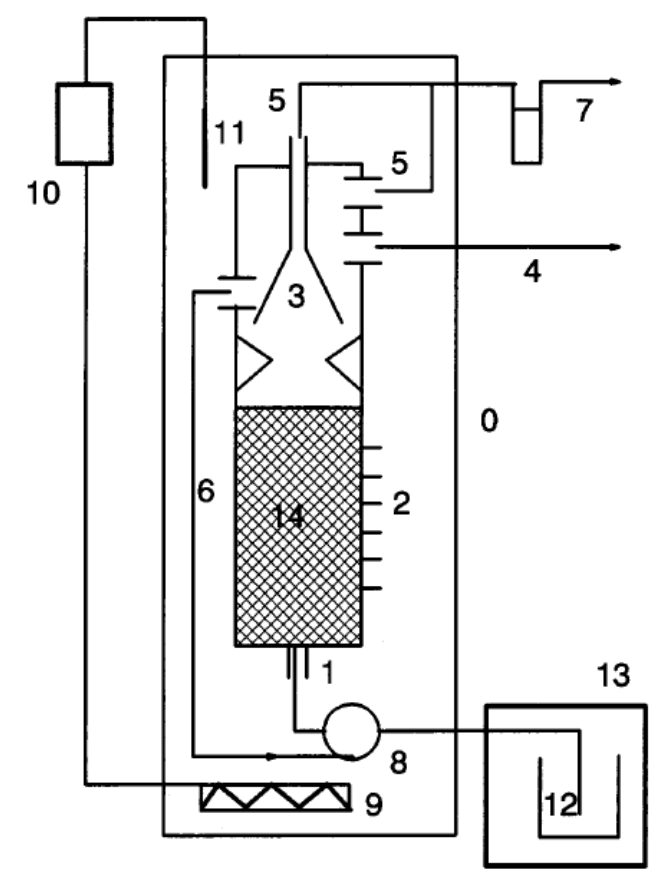

Fig. 1. Scheme of the experimental set-up. 0, Thermostatic chamber; 1, Feed inlet; 2, Sample ports; 3, Gas-solidliquid separator; 4, Effluent outlet; 5, Gas outlet; 6, Effluent recirculation; 7, Gas meter; 8, Feed and recirculation pump; 9, Heater; 10, Temperature controller; 11, Thermometer; 12, Feed vessel; 13, Refrigerator; 14, Raschig rings (only in the $\mathrm{AF}$ ). 


\section{RESULTS}

The slaughtering of animals for commercial meat production is a multistage process, each stage producing wastes with different characteristics. The stages are basically: reception of the livestock, slaughter, separation of the carcass from the offal products, cleaning of the stomach and intestines. In the slaughterhouse studied in this work three effluent lines could be differentiated: the slaughter line which collected blood and wash waters from the killing operation; the line which collected the stomach wash waters; and the line which collected the intestines wash waters and the wastewater from the refrigerated chambers and toilets.

The characteristics of the three effluents are presented in Table 1. The data show wide variations for some of the parameters, due to the discontinuity of the process, leading to daily, weekly and seasonal differences. All samples were pretreated by filtering them through a $1 \mathrm{~mm}$ metallic mesh.

Table 1. Characterization of slaughterhouse wastewaters

\begin{tabular}{llllllll}
\hline Origina $\mathrm{pH}$ & $\mathrm{T}(\mathrm{OC})$ & $\mathrm{TSS}$ & CODt & CODs & Proteins & P-Po - & N-NH3 \\
& & & & & & & \\
& & & & & & \\
\hline Slaughter6.6-6.9 & 35 & $500-1500$ & $7800-15900$ & $7000-13600$ & $4200-10000$ & $1.3-12.8$ & $54.6-$ \\
Stomach 7.1-7.8 & 23 & $1100-2300$ & $2500-4700$ & $900-1200$ & $400-700$ & $0.8-1.21$ & $9.7-33.7$ \\
Intestine 6.7-7.2 & $18-36$ & $1100-2100$ & $700-5200$ & $400-3100$ & $300-2400$ & $36.1-41.7$ & $17.3-$ \\
& & & & & & & 29.9
\end{tabular}

All the units in $\mathrm{mg} / 1 \mathrm{cxcept} \mathrm{pH}$ and $T$.

Of the three lines, the slaughter line shows the highest organic matter concentration, with an average COD of $8000 \mathrm{mg} / \mathrm{l}$, reaching a maximum value of $16,000 \mathrm{mg} / \mathrm{l}$. This stream has a high protein concentration, which can represent up to $70 \%$ of the COD. However, this line shows the lowest suspended solids content, accounting for 15-30\% of the COD, while in the other two streams it accounts for more than $50 \%$ of the COD. The slaughter-line wastewater was selected for the present study. Its characteristics at the time of the experiments are shown in Table 2. The ammonium and phosphate concentrations in this wastewater were high enough to satisfy the metabolic needs of the anaerobic bacteria.

$\begin{aligned} & \text { Table 2. Characteristics of the slaughterhouse wastewater } \\
& \text { fed to the reactors }\end{aligned}$
\begin{tabular}{lcc}
\hline Parameter & Interval & Average \\
\hline COD & $5200-11400$ & $7540 \pm 1290$ \\
TSS & $573-1690$ & $1206 \pm 312$ \\
$\%$ COD insoluble & $12-33$ & $22 \pm 5$ \\
Proteins & $3250-7860$ & $5790 \pm 1540$ \\
Fats & $210-710$ & $415 \pm 166$ \\
$\mathrm{P}_{\mathrm{PO}}^{3-}$ & $7.6-28.3$ & $19.9 \pm 8.4$ \\
$\mathrm{~N}_{4}-\mathrm{NH}_{3}$ & $19-74$ & $44 \pm 19$ \\
pH & $6.8-7.8$ & $7.2 \pm 0.2$ \\
\hline $\mathrm{All}$ & &
\end{tabular}

All the units in $\mathrm{mg} / \mathrm{l}$ except $\mathrm{pH}$. 


\section{Wastewater biodegradability}

The data of the wastewater batch biodegradability test are presented in Table 3 . The rates of conversion to acid and gas products together with the overall biodegradation are shown in Fig. 2. Acidification was rapid (conversion of the organic matter to VFA), whereas the rate of methanization was slower and more uniform, and did not reach a maxi- mum within the test period.

Table 3. Conditions and results of the biodegradability assay

\begin{tabular}{|c|c|c|c|c|}
\hline \multicolumn{5}{|l|}{ Assay conditions } \\
\hline $\begin{array}{l}\text { Reactor volume } \\
0.31\end{array}$ & $\begin{array}{l}\text { Type } \\
\text { static }\end{array}$ & $\begin{array}{l}\text { Temperature } \\
37^{\circ} \mathrm{C}\end{array}$ & $\begin{array}{l}\text { Sludge conc. } \\
1.5 \mathrm{~g} \text { VSS } / 1\end{array}$ & $\begin{array}{l}\text { Sludge activity } \\
0.64 \mathrm{~g} \text { COD } / \mathrm{gVSS} / \text { day }\end{array}$ \\
\hline \multicolumn{5}{|c|}{ Wastewater characteristics } \\
\hline $\begin{array}{l}\text { COD total } \\
10.15 \mathrm{~g} / 1\end{array}$ & $\begin{array}{l}\text { COD soluble } \\
9.1 \mathrm{~g} / 1\end{array}$ & $\begin{array}{l}\text { TSS } \\
0.86 \mathrm{~g} / 1\end{array}$ & $\begin{array}{l}\text { VSS } \\
0.79 \mathrm{~g} / 1\end{array}$ & \\
\hline \multicolumn{5}{|c|}{ Results from 15 days assay referred to the total COD } \\
\hline $\begin{array}{l}\text { Time } \\
360 \mathrm{~h}\end{array}$ & $\begin{array}{l}\text { Methanization } \\
58 \%\end{array}$ & $\begin{array}{l}\text { Acidification }{ }^{\mathrm{a}} \\
58.2 \%\end{array}$ & $\begin{array}{l}\text { Cell yield } \\
13.2 \%\end{array}$ & $\begin{array}{l}\text { Biodegradability } \\
71.4 \%\end{array}$ \\
\hline
\end{tabular}

\%Acidification $=\%$ Methanization $+\%$ VFA.

b $\%$ Cell yield = acidogenics: $Y_{\text {cell }}=0.196 \mathrm{~g} \mathrm{COD}_{\text {cell }} / \mathrm{g} \mathrm{COD}_{\text {elim }}$; methanogenics: $Y_{\text {cell }}=0.028 \mathrm{~g} \mathrm{COD}_{\text {cell }} / \mathrm{g} \mathrm{COD}_{\text {elim}}$.

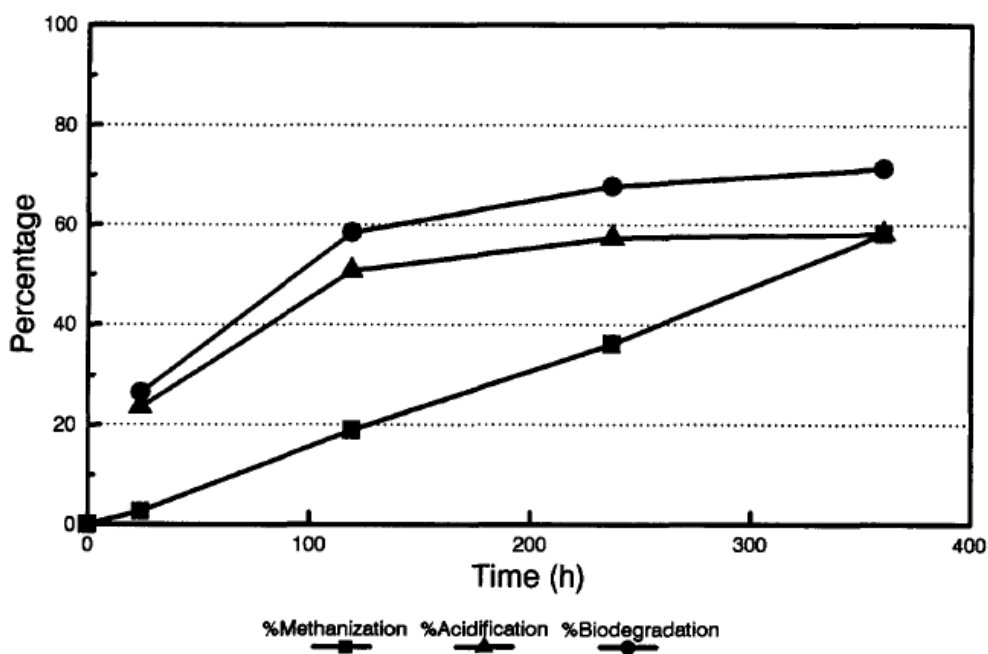

Fig. 2. Biodegradability assay of the slaughter line wastewater.

\section{UASB reactor.}

\section{Start-up}

Start-up of the UASB reactor lasted 117 days. The reactor was fed intermittently to allow a high con- centration of substrate in the inlet stream. A continuous recycle feed ratio of 1:1 was applied to homogenize the sludge and allow an efficient bio- mass growth. During the first 24 days the reactor was fed a synthetic medium containing an easily degradable substrate using a mixture of glucose and nutrients (Field et al., 1988), with a COD of $7 \mathrm{~g} / \mathrm{l}$. During that 
period the average OLR was $0.6 \mathrm{~kg} \mathrm{COD} / \mathrm{m}^{3} /$ day. On day 25 slaughterhouse wastewater was added to the feed and the concentration of glucose was decreased progressively down to zero over a period of 92 days. The presence of glucose in the feed allowed attainment of an OLR of $1 \mathrm{~kg} C O D / \mathrm{m}^{3} / \mathrm{day}$.

\section{Operation}

The total and soluble COD of the feed and of the effluent during the operation period, and the results for the different loading regimes and hydraulic retention times are summarized in Table 4. Between days 118 and 319, the reactor was operated in a continuous mode. The slaughterhouse wastewater concentration was maintained between 5.5 and $9 \mathrm{~kg} \mathrm{COD} / \mathrm{m}^{3}$ and the percentage suspended solids, expressed as COD, between 15 and 30\%. The OLR was increased progressively, from $1 \mathrm{~kg} \mathrm{COD} / \mathrm{m}^{3} /$ day to $6.5 \mathrm{~kg} \mathrm{COD} / \mathrm{m}^{3} /$ day by varying the HRT from 6.5 to 1.2 days.

As can be seen from Fig. 3, the UASB reactor showed a stable behavior up to an OLR of $5 \mathrm{~kg} \mathrm{COD} /{ }^{3} \mathrm{~m} /$ day, reaching removal efficiencies higher than 90\%. For all OLR applied, the methanization was 60\%. During the operational period, the con- centration of solids increased as a result of biomass growth and solids retention.

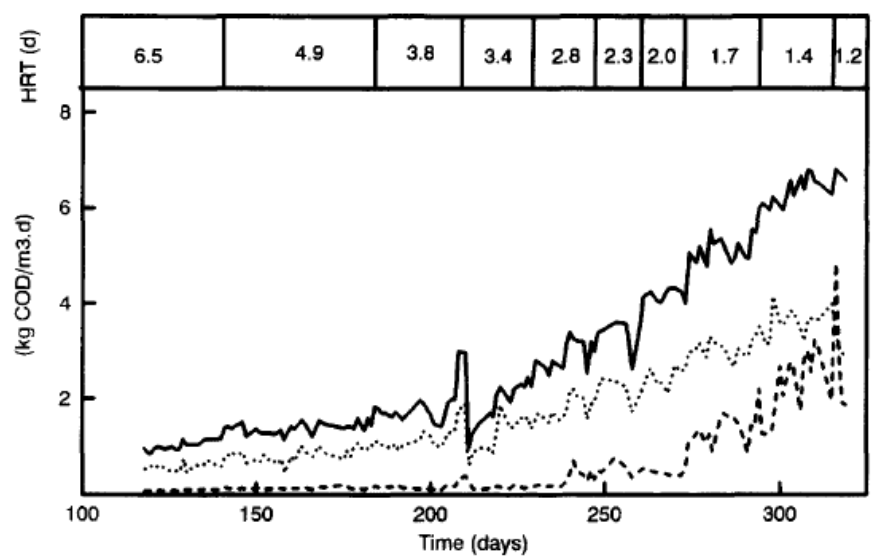

Fig. 3. Organic loading rate of the feed $(-), \mathrm{kg} \mathrm{COD} / \mathrm{m}^{3}$ digester $/$ day of the effluent (-) and $\mathrm{kg} \mathrm{COD} / \mathrm{m}^{3} \mathrm{digester} / \mathrm{day}$ of the methane in the biogas (...) during the operation period of the UASB reactor.

At OLR higher than $5 \mathrm{~kg} \mathrm{COD} / \mathrm{m}^{3} /$ day, the reactor performance declined (Fig. 3 ) and sludge flotation was observed. The concentration of solids in the effluent increased. The soluble COD removal efficiency and the methanization remained constant. The total COD removal efficiency at an OLR of6.5 $\mathrm{kg} \mathrm{COD} / \mathrm{m}^{3} /$ day decreased from 90 to $59 \%$.

During the operational period the $\mathrm{pH}$ remained constant, between 7.5 and 8 . The ammonium concentration varied between 461 and $783 \mathrm{mg} / 1$

(Table 4).

At the end of the experiment, the methanogenicactivity was measured at different reactor depths. In the lower part of the reactor the VSS concentration was $8 \mathrm{~g} / \mathrm{l}$ and the methanogenic activity was $0.44 \mathrm{~kg} \mathrm{COD}_{\mathrm{CH} 4} / \mathrm{g} \mathrm{VSS} /$ day, while the VSS concentration was $2 \mathrm{~g} / 1$ and the methanogenic activity was $0.29 \mathrm{~g}$ $\mathrm{COD}_{\mathrm{CH} 4} / \mathrm{g}$ VSS/day in the upper part of the reactor. The biomass concentration was lower in the upper part of the reactor where the methanogenic activity was the lowest, possibly due to the accumulation of more recalcitrant material. 
Table 4. Summary of the operation period in the UASB reactor

\begin{tabular}{|c|c|c|c|c|c|c|c|c|c|c|c|}
\hline \multirow{2}{*}{$\begin{array}{l}\text { Period } \\
\text { (days) }\end{array}$} & \multirow{2}{*}{$\begin{array}{l}\text { HRT } \\
\text { (days) }\end{array}$} & \multicolumn{2}{|c|}{ Feed } & \multicolumn{3}{|c|}{ Effluent } & \multirow{2}{*}{$\begin{array}{c}\text { Biogas } \\
\begin{array}{c}\mathrm{CH}_{4} \\
\left(\mathrm{~m}^{3} / \mathrm{m}^{3} / \text { day }\right)\end{array}\end{array}$} & \multicolumn{3}{|c|}{ Removal } & \multirow{2}{*}{$\begin{array}{c}\text { Methan. } \\
\text { (\%) }\end{array}$} \\
\hline & & $\begin{array}{l}\text { OLRt } \\
\text { (kg COD }\end{array}$ & $\begin{array}{r}\text { OLRs } \\
/ \mathrm{m}^{3} / \text { day) }\end{array}$ & $\begin{array}{l}\text { CODe } \\
(\mathrm{mg} / 1)\end{array}$ & $\begin{array}{c}\mathrm{SSe} \\
(\mathrm{mgCOD} / \mathrm{l})\end{array}$ & $\begin{array}{c}\mathrm{N}-\mathrm{NH}_{3} \\
(\mathrm{mg} / \mathrm{l})\end{array}$ & & CODt & $\begin{array}{c}\text { CODs } \\
(\%)\end{array}$ & Proteins & \\
\hline $118-140$ & $6.5 \pm 0.8$ & $1.03 \pm 0.1$ & $0.78 \pm 0.1$ & $585 \pm 51$ & $195 \pm 53$ & $663 \pm 38$ & $0.22 \pm 0.03$ & $91.3 \pm 0.8$ & $92.4 \pm 0.8$ & $95.1 \pm 0.2$ & $56.4 \pm 5.6$ \\
\hline $141-183$ & $4.9 \pm 0.5$ & $1.39 \pm 0.1$ & $1.08 \pm 0.1$ & $637 \pm 79$ & $196 \pm 81$ & $726 \pm 66$ & $0.32 \pm 0.05$ & $90.4 \pm 1.3$ & $91.5 \pm 0.8$ & - & $58.9 \pm 7.0$ \\
\hline $184-207$ & $3.8 \pm 0.4$ & $1.74 \pm 0.2$ & $1.24 \pm 0.2$ & $608 \pm 119$ & $228 \pm 68$ & $461 \pm 118$ & $0.43 \pm 0.05$ & $91.1 \pm 1.6$ & $91.7 \pm 1.4$ & - & $64.5 \pm 5.0$ \\
\hline $208-229$ & $3.4 \pm 0.2$ & $2.23 \pm 0.2$ & $1.86 \pm 0.1$ & $544 \pm 38$ & $306 \pm 51$ & $485 \pm 40$ & $0.60 \pm 0.07$ & $93.0 \pm 1.0$ & $96.4 \pm 1.0$ & - & $70.6 \pm 7.5$ \\
\hline $230-247$ & $2.8 \pm 0.2$ & $2.92 \pm 0.3$ & $2.46 \pm 0.2$ & $896 \pm 380$ & $700 \pm 410$ & $611 \pm 14$ & $0.69 \pm 0.09$ & $89.5 \pm 4.5$ & $97.0 \pm 0.6$ & $98.4 \pm 0.1$ & $61.2 \pm 3.5$ \\
\hline $248-260$ & $2.3 \pm 0.4$ & $3.35 \pm 0.4$ & $2.70 \pm 0.5$ & $1196 \pm 200$ & $943 \pm 180$ & - & $0.83 \pm 0.09$ & $84.6 \pm 3.0$ & $95.6 \pm 1.8$ & $95.6 \pm 0.3$ & $64.7 \pm 4.1$ \\
\hline $261-273$ & $2.0 \pm 0.1$ & $4.17 \pm 0.1$ & $3.09 \pm 0.2$ & $940 \pm 161$ & $540 \pm 192$ & - & $0.95 \pm 0.07$ & $88.7 \pm 1.6$ & $93.4 \pm 1.5$ & $97.2 \pm 0.9$ & $59.5 \pm 4.9$ \\
\hline $274-293$ & $1.7 \pm 0.1$ & $5.15 \pm 0.3$ & $4.20 \pm 0.2$ & $2244 \pm 473$ & $1955 \pm 480$ & $704 \pm 49$ & $1.17 \pm 0.07$ & $74.4 \pm 5.0$ & $95.8 \pm 0.3$ & $97.2 \pm 0.6$ & $58.9 \pm 2.0$ \\
\hline $294-302$ & $1.4 \pm 0.5$ & $6.04 \pm 0.1$ & $4.63 \pm 0.3$ & $2422 \pm 1500$ & $2030 \pm 1500$ & $691 \pm 198$ & $1.34 \pm 0.13$ & $71.4 \pm 9.6$ & $94.0 \pm 2.0$ & $96.7 \pm 1.3$ & $57.8 \pm 5.0$ \\
\hline $303-319$ & $1.2 \pm 0.2$ & $6.58 \pm 0.2$ & $5.26 \pm 0.4$ & $3240 \pm 1180$ & $2772 \pm 1180$ & $783 \pm 235$ & $1.34 \pm 0.13$ & $59.0 \pm 7.8$ & $92.6 \pm 2.0$ & $95.7 \pm 3.3$ & $52.9 \pm 6.0$ \\
\hline
\end{tabular}

After having stopped the reactor operation for one month, the UASB reactor was restarted (day338) at an OLR between 4.5 and $5 \mathrm{~kg} \mathrm{COD} / \mathrm{m}^{3} /$ day and an HRT of 1.5 days (Fig. 4). The COD removal efficiency was then about $75 \%$ and the methanization around 55\%. The reactor operated at this OLR during 72 days, and in order to study the stability of the reactor, hydraulic, organic and thermic shocks were applied, over periods of $15 \mathrm{~h}$. For the hydraulic shock (day 350) the HRT was decreased from 1.5 to0.8 days which increased the OLR from 4.7 to $9 \mathrm{~kg}$ $\mathrm{COD} / \mathrm{m}^{3} /$ day. For the organic shock (day 372) an OLR of $14 \mathrm{~kg} \mathrm{COD} / \mathrm{m}^{3} /$ day was applied by feeding a highly concentrated wastewater of $17 \mathrm{~g}$ COD/1. In both cases the removal efficiency and the methanization first decreased, but later quickly recovered. During the hydraulic shock the COD removal efficiency decreased by $10 \%$ and methanization by $20 \%$, as compared to the last OLR applied. During the organic shock these values decreased by $25 \%$ and $20 \%$, respectively. The third experiment consisted in switching off the heating system for one day (day385), maintaining the reactor at room temperature (about $\left.20^{\circ} \mathrm{C}\right)$. The methane c onversion decreased during the temperature shock by $20 \%$ and the COD removal efficiency decreased by $15 \%$. When the temperature was again set at the original value of $37^{\circ} \mathrm{C}$, the methanization rate and the removal efficiency recovered. For the three different shocks applied the system recovered in about $24 \mathrm{~h}$. 


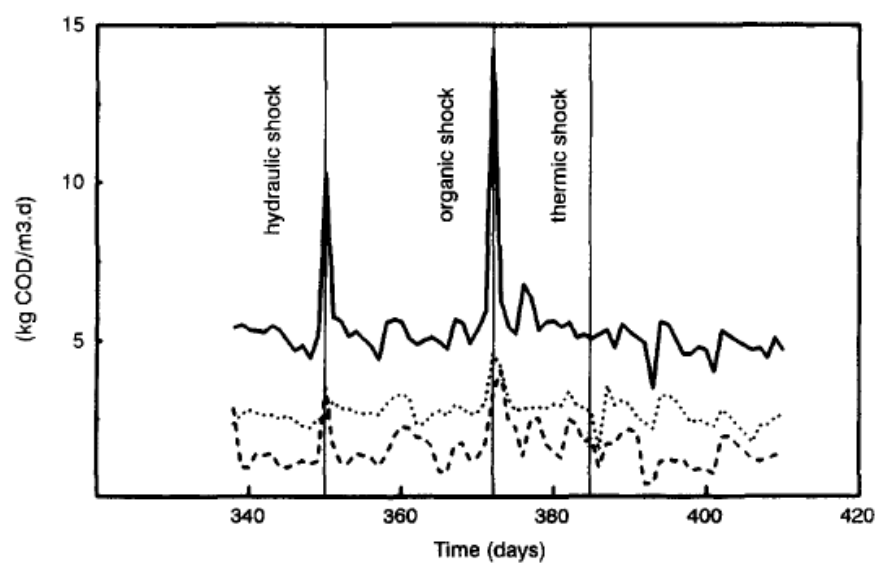

Fig. 4. Organic loading rate of the feed (-), $\mathrm{kg} \mathrm{COD} / \mathrm{m}^{3}$ digester $/$ day of the effluent $(-)$ and $\mathrm{kg} \mathrm{COD} / \mathrm{m}^{3} \mathrm{digester} / \mathrm{day}$ of the methane in the biogas (...) during the shocks period of the UASB reactor.

\section{Anaerobic filter}

Start-up

Raw wastewater, without dilution, was applied at an OLR of $0.5 \mathrm{~kg} \mathrm{COD} / \mathrm{m}^{3} / \mathrm{day}$. To allow a homogeneous and effective colonization of the support material, a recycle:feed ratio of 6:1 was applied. On day 20 the OLR was increased to $1 \mathrm{~kg}$ $\mathrm{COD} / \mathrm{m}^{3} /$ day, corresponding to a HRT of seven days. At such OLR the COD removal efficiency was high, about 90\%, however, conversion of COD to methane needed 50 days to increase from 30 to $50 \%$. The OLR was progressively increased from 1 to $4 \mathrm{~kg} \mathrm{COD} / \mathrm{m}^{3} /$ day. When the steady-state was reached, the reactor was stopped for one month to check the time needed to restart it, after a preliminary adaptation.

Operation

The reactor was restarted, and the organic loading rate was progressively increased over the operational period (Table 5).

Total and soluble COD of the feed and effluent are presented in Table 5 for that period. The influent $\mathrm{OLR}, \mathrm{kg} \mathrm{COD} / \mathrm{m}^{3}$ digester/day of the effluent and $\mathrm{kg}$ $\mathrm{COD} / \mathrm{m}^{3}$ digester/day of the methane in the biogas are shown in Fig. 5.

Increasing OLR were applied, from 0.5 up to $6 \mathrm{kgCOD} / \mathrm{m}^{3} /$ day, by progressively decreasing the HRT to 1.5 days. During this 91 day period, the removal of COD was $63-84 \%$.

At OLR higher than $6 \mathrm{~kg} \mathrm{COD} / \mathrm{m}^{3} /$ day, the total removal efficiency decreased to $50 \%$. A wash-out of insoluble matter was observed, but the concentration

of soluble matter in the effluent remained constant, indicating that the filter was clogged.

The reactor worked up to $11 \mathrm{~kg} \mathrm{COD} / \mathrm{m}^{3} /$ day. At the latter OLR a decrease in reactor performance was observed, with acidification and a large wash-out of sludge.

Then the OLR was decreased to $5 \mathrm{~kg} \mathrm{COD} / \mathrm{m}^{3}$ day (Fig. 6) to operate the reactor under steady-state conditions. Afterwards an organic shock was applied by increasing the OLR to $14 \mathrm{~kg} \mathrm{COD} / \mathrm{m}^{3} /$ day for $6 \mathrm{~h}$. A large acidification was observed in the effluent, corresponding to a decreasing removal efficiency. When the OLR was restored to its previous value (5 kg $\mathrm{COD} / \mathrm{m}^{3} /$ day), the initial biogas production and the effluent characteristics were recovered in less than $24 \mathrm{~h}$.

After operating under steady-state conditions for several weeks, a thermic shock 
was applied by switching off the heating system for a period of $12 \mathrm{~h}$. The subsequent temperature decrease completely inhibited the methanization process and resulted in a slight decrease in removal efficiency. When the temperature was again set at the original value of $37^{\circ} \mathrm{C}$, the methanization rate recovered in $18 \mathrm{~h}$. The methanogenic activities of the attached and suspended sludge were measured at different reactor heights at the end of the operation period. During the period of operation, the activity, expressed as kgCODcH4/kg VSS/day, decreased by 28 and $90 \%$ in the upper and lower parts of the reactor, respectively.

From these results, it can be concluded that both the organic and thermic shocks presented no permanent effects on the stability of the filter.

Table 5. Summary of the operation period in the AF

\begin{tabular}{|c|c|c|c|c|c|c|c|c|c|c|c|}
\hline \multirow{2}{*}{$\begin{array}{l}\text { Period } \\
\text { (days) }\end{array}$} & \multirow{2}{*}{$\begin{array}{l}\text { HRT } \\
\text { (days) }\end{array}$} & \multicolumn{2}{|c|}{ Feed } & \multicolumn{3}{|c|}{ Effluent } & \multirow{2}{*}{$\begin{array}{c}\text { Biogas } \\
\begin{array}{c}\mathrm{CH}_{4} \\
\left(\mathrm{~m}^{3} / \mathrm{m}^{3} / \text { day }\right)\end{array}\end{array}$} & \multicolumn{3}{|c|}{ Removal } & \multirow{2}{*}{$\begin{array}{c}\text { Methan. } \\
(\%)\end{array}$} \\
\hline & & $\begin{array}{l}\text { OLRt } \\
\text { (kg COD) }\end{array}$ & $\begin{array}{r}\text { OLRs } \\
\left./ \mathrm{m}^{3} / \text { day }\right)\end{array}$ & $\begin{array}{l}\text { CODe } \\
(\mathrm{mg} / \mathrm{l})\end{array}$ & $\begin{array}{c}\mathrm{SSe} \\
(\mathrm{mgCOD} / \mathrm{l})\end{array}$ & $\begin{array}{c}\mathrm{N}-\mathrm{NH}_{3} \\
(\mathrm{mg} / \mathrm{l})\end{array}$ & & CODt & $\begin{array}{l}\text { CODs } \\
(\%)\end{array}$ & Proteins & \\
\hline $04-218$ & $7.1 \pm 1.0$ & $0.88 \pm 0.3$ & $0.51 \pm 0.2$ & & & & $0.05 \pm 0.04$ & & & - & $18.1 \pm 11.3$ \\
\hline & $4.0 \pm 0.2$ & $1.45 \pm 0.2$ & $1.03 \pm 0.2$ & $1040 \pm 161$ & $680 \pm 50$ & $579 \pm 71$ & $0.20 \pm$ & $82.3 \pm 2.5$ & & - & \\
\hline $28-232$ & $2.7 \pm 0.1$ & $2.01 \pm 0.1$ & $1.20 \pm 0.1$ & $891 \pm 101$ & $405 \pm 45$ & $803 \pm 134$ & $0.35 \pm$ & $83.6 \pm 2.0$ & $85.2 \pm 2.0$ & $95 \pm 0.2$ & $44.8 \pm 3.5$ \\
\hline $233-244$ & $2.6 \pm 0.3$ & $2.36 \pm 0.2$ & $2.10 \pm 0.3$ & $1586 \pm 700$ & $494 \pm 130$ & $752 \pm 61$ & $0.46 \pm$ & $68.7 \pm 11$ & $79.9 \pm 10$ & - & $51.1 \pm 6.0$ \\
\hline $245-251$ & $2.1 \pm 0.1$ & $2.96 \pm 0.1$ & $2.72 \pm 0.1$ & $1785 \pm 450$ & $735 \pm 200$ & $814 \pm 69$ & $0.57 \pm$ & $71.2 \pm 8.5$ & $81.7 \pm 5.0$ & $98 \pm 0.1$ & \\
\hline & $1.9 \pm$ & $3.64 \pm 0.3$ & & $2603 \pm 750$ & $1311 \pm 300$ & - & & & & & \\
\hline $59-269$ & $2.1 \pm$ & $3.91 \pm$ & $2.99 \pm$ & $2940 \pm$ & $567 \pm 287$ & $449 \pm 77$ & $0.68 \pm$ & $65.1 \pm$ & $62.3 \pm 10$ & $97 \pm 0.2$ & \\
\hline $270-286$ & $1.8 \pm 0.1$ & $4.63 \pm 0.2$ & $3.50 \pm 0.2$ & $2322 \pm 590$ & $828 \pm 407$ & - & $0.84 \pm 0.07$ & $72.1 \pm 7.4$ & $76.3 \pm 6.6$ & $96 \pm 0.1$ & $47.1 \pm 4.0$ \\
\hline $287-293$ & $1.6 \pm 0.1$ & $5.26 \pm 0.2$ & $3.87 \pm 0.7$ & $3056 \pm 200$ & $1088 \pm 230$ & - & $0.95 \pm 0.04$ & $63.6 \pm 6.4$ & $68.3 \pm 3.3$ & - & $46.9 \pm 2.3$ \\
\hline $294-302$ & $1.5 \pm 0.3$ & $6.16 \pm 0.7$ & $3.10 \pm 0.7$ & $3345 \pm 190$ & $1695 \pm 240$ & $687 \pm 140$ & $1.10 \pm 0.14$ & $63.4 \pm 0.6$ & $44.9 \pm 6.4$ & $97 \pm 0.1$ & $46.5 \pm 3.4$ \\
\hline $329-334$ & $0.6 \pm 0.1$ & $8.36 \pm 0.5$ & $7.03 \pm 0.7$ & $2868 \pm 350$ & $1494 \pm 300$ & $980 \pm 178$ & $1.06 \pm 0.09$ & $42.6 \pm 8.5$ & $67.4 \pm 8.0$ & - & $33.0 \pm 3.8$ \\
\hline $335-338$ & $0.5 \pm 0.1$ & $11.21 \pm 0.1$ & $10.25 \pm 0.1$ & $4015 \pm 250$ & $2430 \pm 200$ & $872 \pm 137$ & $1.05 \pm 0.01$ & $28.4 \pm 5.0$ & $69.1 \pm 5.0$ & $95 \pm 0.2$ & $24.3 \pm 0.1$ \\
\hline
\end{tabular}

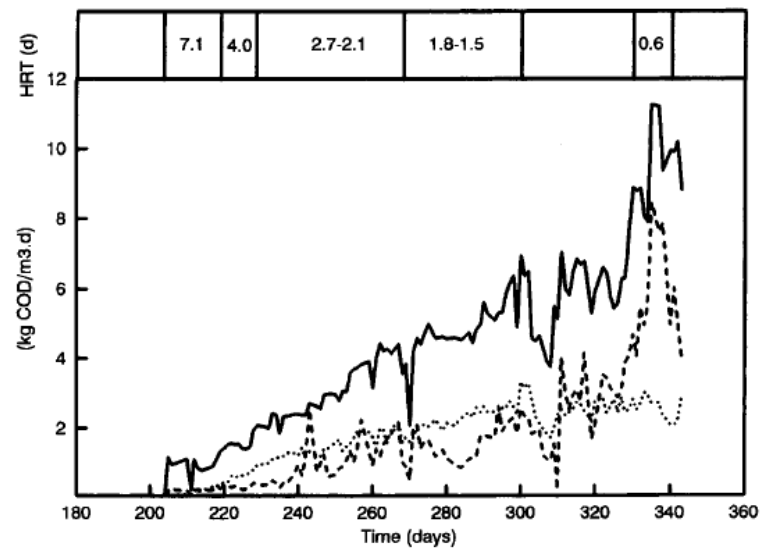

Fig. 5. Organic loading rate of the feed $(-), \mathrm{kg} \mathrm{COD} / \mathrm{m}^{3}$ digester/day of the effluent $(-)$ and $\mathrm{kg} \mathrm{COD} / \mathrm{m}^{3}$ digester $/$ day of the methane in the biogas (...) during the operation period of the AF. 


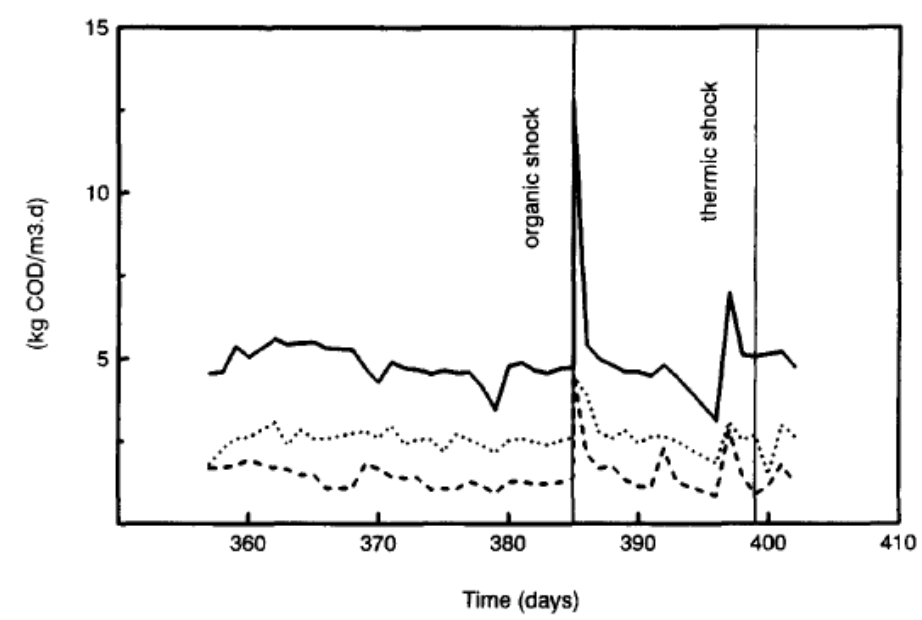

Fig. 6. Organic loading rate of the feed $(-), \mathrm{kg} \mathrm{COD} / \mathrm{m}^{3}$ digester $/$ day of the effluent $(-)$ and $\mathrm{kg} \mathrm{COD} / \mathrm{m}^{3}$ digester $/$ day of the methane in the biogas (...) during the shocks period of the AF.

\section{DISCUSSION}

The overall organic load of the slaughterhouse wastewater studied in the present work had an aver-age value of $8000 \mathrm{mg} \mathrm{COD} / 1$, which is higher than for other slaughterhouse wastewaters described in the literature (Sayed et al., 1984, 1987; Polprasert et al., 1992; Campos et al., 1986). This is mainly dueto the fact that in the present study the blood was not previously recovered as a by-product, leading to a very high concentration of proteins in the waste- water. Because of the wastewater characteristics the addition of nutrients was not necessary, since they were available in adequate concentrations.

A good anaerobic biodegradability was observed, reaching $71.4 \%$ in 15 days. The organic matter was methanized up to 58\% (Table 3). However, the acidification rate was higher than the methanization rate, which could be due to an initial methanogenic toxicity of the wastewaters, resulting probably from a high level of ammonium originating from the hydro- lysis of proteins, or because the methanogenic bacteria were not well adapted to the substrate.

In the continuous studies, both reactors showed a good performance for OLR lower than $6.5 \mathrm{~kg} \mathrm{COD} / \mathrm{m}^{3} /$ day. For similar OLR the UASB showed higher removal efficiencies than the AF. Similar results were obtained by Tritt \& Schuchardt, 1992 with two fixed-bed reactors for the same OLR, using two different carriers (bamboo and bones).

At higher OLR the AF was destabilized. The total and soluble COD removals decreased and a high wash-out of solids was observed. At the same OLR the UASB also started to destabilize, but the soluble COD removal remained high. At higher OLR, sludge flotation was observed leading to a loss of active biomass from the UASB reactor. Sayed \& de Zeeuw (1988b) observed the same phenomenum working with a less concentrated wastewater in a flocculent sludge UASB reactor at $30^{\circ} \mathrm{C}$. A continuing accumulation of substrate materials, either coarse suspended solids, colloidal matter or soluble components of the wastewater, also led to sludge flotation and consequently to a loss of active biomass from the reactor. Accumulation of substrate components from slaughterhouse wastewaters is detrimental to the stability of the anaerobic treatment process provoking a significant drop in the specific activity of the 
sludge and Jeading ultimately to the sludge wash out.

A long term stability of the process could be maintained by applying an OLR lower than $5 \mathrm{~kg} \mathrm{COD} / \mathrm{m}^{3} /$ day. If excessive accumulation of organic matter occurs one should try to convert this organic matter into methane, e.g. by removing sludge and digesting it in a separate digester. After stabilization the sludge could be returned to the UASB or AF reactors.

Both reactors recovered well after the organic and hydraulic shocks, in less than $24 \mathrm{~h}$.

There was no need to artificially regulate the $\mathrm{pH}$, since it remained constant, between 7.5 and 8, during the whole operation period.

From these data it is possible to conclude that the anaerobic digestion is an efficient treatment method for slaughterhouse wastewaters with a high organic matter content and a considerable nitrogen (ammonium) concentration. In the present experiments ammonium carne from the degradation of proteins present in the wastewater and reached concentrations between 461 and $980 \mathrm{mg} / \mathrm{l}$ in both reactors.

The final effluent should undergo an additional treatment e.g. an aerobic biological process to eliminate the ammonium and residual fraction of organic matter.

\section{ACKNOWLEDGEMENTS}

This work was supported by a grant from the University of La Coruña.

\section{REFERENCES}

APHA-AWWA-WPCF (1992). Standard Methods for the Examination of Water and Wastewater, 18th edn, Wash- ington, OC, USA.

Campos, J. R., Foresti, E. \& Camacho, R. D. P. (1986). Anaerobic wastewater treatment in the food processing industry: two case studies. Wat. Sci. Tech., 12, 8797.

Couillard, D., Gariépy, S. \& Tran, F. T. (1989). Slaughterhouse effluent treatment by thermophilic aerobic process. Water Research, 23, 573-579.

Field, J., Sierra, R. \& Lettinga, G. (1988). Ensayos anaerobios. Proc. of 4th Symp. on Wastewater Anaerobic Treatment. Valladolid, Spain, pp. 52-81.

Gariépy, S., Tyagi, R. D., Couillard, D. \& Tran, F. (1989). Thermophilic process for protein recovery as an alternative to slaughterhouse wastewater treatment Biological Wastes, 29, 93-105.

Hickey, R., Wu, W., Jones, R. \& Veiga, M. C. (1992). The start-up, operation, monitoring and control of high-rate anaerobic treatment systems. Water Science and Tech-nology, 24, 207-255.

Lowry, O. H., Rosenbrough, N., Farr, A. L. \& Randall, R. J. (1951). Protein measurements with the Folin phenol reagent J. Biol. Chem., 193, 265-275.

Marchaim, U., Levanon, D., Danai, 0., Musaphy, S., Chen, Y., Inbar, Y. \& Klinger, 1. (1991). A suggested solution for slaughterhouse wastes: uses of the residual materials water anaerobic digestion. Biores. Technol., 37, 127-134.

Mateu, A., Mata-Alvarez, J. \& Parés, R. (1992). Enterobacterial and viral decay experimental models for anaerobic digestion of piggery waste.Appl.microbio/. Biotechnol., 38, 291-296.

Peláez, J. A., Martínez, B. \& Fdez.-Polanco, F. (1989). Aplicación de un reactor anaerobio UASB a la depura- ción de aguas residuales de un matadero frigorífico. Tecnología del Agua, 62, 73-80.

Polprasert, C., Kemmadamrong, P. \& Tran, F. T. (1992). Anaerobic Baffle Reactor (ABR) process for treating a slaughterhouse wastewater. Enviran. Technol., 13, 857-865.

Ruiz, 1.,'Santiago, P., Veiga, M. C. \& Blázquez, R. (1993).

Características de los efluentes de matadero. Revisión de las alternativas de tratamiento. Alimentación, equipos y tecnología. Septiembre, pp. 77-83.

Ruiz, 1. (1992). Tratamiento de aguas residuales de matadero mediante un reactor anaerobio tipo UASB. Tesis de Licenciatura. Universidad de La Coruña.

Sáez, J. \& Martínez, A. (1987). Estudio comparativo de distintos coagulantes inorgánicos en el tratamiento de efluentes líquidos de matadero. Tecnología del Agua, 39, 96-100.

Sayed, S., van der Zanden, J., Wijffels, R. \& Lettinga, G. 
(1988). Anaerobic degradation of the various fractions

of slaughterhouse wastewater. Biological Wastes, 23,117-142.

Sayed, S. \& de Zeeuw, W. (1988). The performance of a continuously operated flocculent sludge UASB reactor with slaughterhouse wastewater. Biological Wastes, 24,199-212.

Sayed, S., van Campen, L. \& Lettinga, G. (1987). Anaero-bic treatment of slaughterhouse waste using a granular sludge UASB reactor. Biological Wastes, 21, $11-28$.

Sayed, S., de Zeeuw, W. \& Lettinga, G. (1984). Anaerobic treatment of slaughterhouse waste using a flocculent sludge UASB reactor. Agricultura/ Wastes, 11, 197-226.

Soto, M., Méndez, R. \& Lema, J. M. (1993). Methanogenic and nonmethanogenic activity tests: Theoretical basis and experimental set up. Water Research, 21, 1361-1376.

Tritt, W. P. \& Schuchardt, F. (1992). Materials flow and possibilities of treating liquid and solid wastes from slaughterhouses in Germany. A review. Biores. Technol., 41, 235-245.

Veiga, M. C., Méndez, R. \& Lema, J. M. (1994). Wastewater treatment for fisheries operations. In Fisheries Processing: Biotechnological Applications, ed. A. M. Mar- tin. Chapman and Hall, UK, Chapter 14, pp. 344-369. 